\title{
Referendum, Initiative, and Veto Power: Budgetary Decision Making in Local Government
}

\author{
BERNARD STEUNENBERG*
}

\section{INTRODUCTION}

Political institutions appear to affect outcomes of public decision making ${ }^{1}$. Several studies have provided empirical evidence in favor of this hypothesis, comparing local governments using town meeting procedures with those using a representative system (see POMMEREHNE [1978]; POMMEREHNE and SCHNEIDER [1982]; SANCERRE [1986]). However, this simple institutional view is not always supported. Comparing the provision of rural roads by townships in Illinois and Minnesota, CHICOINE, WALZER and DELLER [1989] found no clear difference between direct and representative forms of government. MORGAN and PELISSERO simultaneously examined the form of government, the way in which government officials were elected and whether or not elections can be classified as partisan in 22 U.S. cities for an 11-year period. They concluded that '...changes in city government structure have almost no impact on changes in taxing and spending levels' [1980, 1005]. FARNHAM analyzed the influence of the same variables on the level of public spending for a sample of 633

*University of Twente, Faculty of Public Administration and Public Policy, Department of Economics, P.O. Box 217,7500 AE Enschede, The Netherlands. This paper was written during my stay at the Department of Economics of the University of Maryland, College Park, and the Center for Study of Public Choice, George Mason University, Fairfax, Virginia, U.S.A. Preliminary versions were presented at Aubum University, the Workshop in Political Theory and Policy Analysis of Indiana University, the Center for Study of Public Choice, the 1991 Public Choice Society Meeting in New Orleans, and the University of Maryland and College Park. I would like to thank the participants of these workshops and especially DENNSS MUELUER forhelpful comments. The research is supported with a gran of the Netherlands Organization for Scientific Research (NWO) and the Moret Foundation (Stichting Moret Fonds).

1. See for a survey of empirical research: POMMERERNE [1990]. 
communities with populations of 10,000 or more persons. He found that 'if the reformed government characteristics are included directly as dummy variables in equations using all observations, their effect on expenditure is not statistically significant' [1987, 580]. In another comparative study FARNHAM attempted to assess the effects of three forms of citizen influence in representative systems on the level of public expenditure. He concluded that "...the influence of the initiative, referendum, and recall like that of the reformed characteristics... is either very modest or cannot be detected with the methodology used in this paper' [1990, 211]. Again, empirical evidence seems to be hardly supportive for an institutional view on decision making.

However, these studies are limited in dealing with political institutions ${ }^{2}$. First, none of these studies deals with institutional arrangements on a systematic basis. Using the median voter theorem, it is simply argued that policies in a representative system contain more 'white noise' than those in a direct democracy because of the influence of bureaucracy and other special interest groups. The effect of different arrangements of representative government on outcomes of decision making remains unclear. Second, most studies only make a distinction between direct and representative democracies neglecting other institutional features. They fail to take into account the influence of arrangements such as referendum and voter initiative in the case of representative government, which may lead to outcomes that are not simply a larger or smaller deviation of median voter preferences. The neglected interdependence of different institutions may also be a reason why some studies do not find empirical support for the influence of political institutions on expenditure levels, especially those dealing with comparisons between representative forms of government. Third, some studies simply assume identical or strongly comparable preferences for the supply side of government (that is, legislators, elected officials of the executive branch, and bureaucrats), which only differ from voter preferences. Furthermore, voters are typically assumed to favor lower levels of spending ${ }^{3}$. One might question whether the assumption about a 'homogenous' supply side is supported by behavioral models of politicians and bureaucrats. Moreover, such an assumption passes over arrangements (for instance, veto power) that might greatly influence outcomes of decision making

2. Following FrEY $[1990,444]$ institutions can be defined as arrangements that structure repeated human behavior. These arrangements can be distinguished into two major types: (1) rules and (2) organizations. This paper focuses on the influence of rules.

3. A recent example is FARNHAM who argues that 'fi]f Leviathan or budget-maximizing tendencies are at work on the supply side, the direct democracy variables should have negative coefficients indicating a constraining effect on the level of local public expenditure' $[1990,203]$. 
as soon as differences are perceived in preferences between, for example, legislators and bureaucrats.

The purpose of this paper is to examine the influence of different institutional arrangements of representative government on the level of public expenditure. More specifically, the influence of (1) obligatory fiscal referendum, (2) voter initiative, and (3) veto power of an elected official of the executive branch (for instance, the mayor in some U.S. cities) are analyzed. Furthermore, agenda setting power of bureaucracy is introduced to model a setting in which bureaucracy can be regarded as powerful. This case can be distinguished from one in which a legislative body is able to amend proposals of bureaucracy completely. This allows us to compare the outcomes of both models, which may reveal some of the characteristics of bureaucratic and legislative power in decision making processes under different arrangements.

The paper is organized as follows: Section II. develops a model to analyze different institutional arrangements for budgetary decision making. In Section III.1., the influence of obligatory referendum will be investigated with a bureaucratic agenda setter. The assumption about agenda setting power is modified in Section III.2. allowing the legislature to amend budget proposals. In Section IV.1. an arrangement is introduced that allows voters to propose a level of taxation. Section IV.2. analyzes the effect of indirect initiative. Section V.1. examines the influence of veto power with respect to higher tax rates proposed by the legislature. Relaxing the assumption about agenda setting power, the case in which legislators can amend proposals of the bureaucracy is dealt with in Section V.2. Section VI. concludes the paper and points to some implications of this analysis of political institutions.

\section{BUDGETARY DECISION MAKING}

To show how different institutional arrangements may affect the outcome of budgetary decision making in the public sector, assume a government for which public expenditures are financed by taxes. For simplicity, governments do not have access to capital markets, and they are not allowed to create deficits. So, the level of public expenditures of a government is equal to total tax revenues. Then, budgetary decision making can be viewed as deciding on a single policy dimension, which may represent the level of public spending or the level of taxation. This implies that if the executive branch only has formal veto power with respect to tax legislation (or tax ordinances), this authority can actually be regarded as veto power with respect to the level of spending. Likewise, if voters have the authority to propose ordinances in the case of voter initiative, which 
is formally limited to, for example, the assessment of a (maximum) level of taxation, their authority is equivalent to proposing a level of public expenditure.

All political actors are assumed to have preferences with respect to the level of expenditure, $E$. The preference of a political actor $i$ can be represented with a utility function $U_{i}($.$) defined over E$. These functions are assumed to be identically shaped for all voters as well as for all members of the legislature. However, their form may differ between voters and legislators. Moreover, the utility maximizing actors have single peaked preferences in $E$, which are assumed to be symmetric ${ }^{4}$. The most preferred point by a voter ${ }^{3}$, an elected official or a member of bureaucracy, given some tax structure, is called his ideal point $E^{*}(i)$, which has the following property: $U_{i}\left(E^{*}\right)>U_{i}(E)$ for all $E \neq E^{*}(i)$.

The one-chamber legislature uses majority rule as a decision rule, which implies that the median legislator is decisive in this body. However, the ideal point of the median legislator is not necessarily equal to the median preference of all voters. One way of clarifying this point is to assume that legislators are elected by district. If a legislator represents the median voter within his district ${ }^{6}$, then the preference of the median of all voters is represented by the median legislator if and only if the median voter in the median legislator's district is equivalent to the median of all voters. This condition is very restrictive, and it is generally not likely to be fulfilled. Another reason for differences between voters and representatives are multi-member constituencies in local government. So, given the assumptions introduced, the legislature may approve an expenditure level that deviates from a level preferred by the median voter. As suggested by public choice theory, legislators most likely prefer a higher level of spending than the median voter as they are 'captured' by special interest groups who have some stake in public spending.

A third actor is a non-elected executive, who represents the government bureaucracy. His utility is assumed to be an increasing function of $E$. So, this preference is comparable to that of a NISKANEN-type of bureaucrat. The executive's maximizing behavior is constrained by preferences of the legislature and/or voters, depending on the institutional arrangement that is used.

4. The assumptions about the shape of the uility function avoid unnecessary complications identifying median voters or median legislators for different 'reversion' or 'status quo' levels of spending.

5. See ROMER and ROSENmHal [1979, 565-566] who establish single peaked preferences of voters in this context.

6. This assumption can be questioned as well. 
All political actors are assumed to have full information on the preferences of other actors and the structure of the game. Therefore, every actor is able to anticipate future courses of action ${ }^{7}$. Second, it is assumed that political actors prefer that their decisions are not revised by others. This can be interpreted as having some cost imposed on a proposal that is not the final outcome of the budgetary process. If, for instance, the legislature prefers a budget $E_{L}$, which can be reached by the agency choosing this budget or proposing another budget that will be amended to $E_{L}$, the agency prefers the first. Third, decisions are made in a sequential way, and no one is able to commit to future courses of action. Given these assumptions, the equilibrium concept of subgame perfectness ${ }^{8}$ can be used. It provides a unique outcome for every 'budget' game in this paper ${ }^{9}$, given the preferences of actors, their authority and the sequence of the decision making process. This enables us to compare outcomes for different preferences as well as for different institutional arrangements.

To illustrate the working of the introduced assumptions, consider the following institutional arrangement:

1. The executive proposes a budget (or, a level of $E$ ), and

2. the budget has to be approved by the legislature, who cannot amend the proposal.

This arrangement is normally used in 'traditional' models of budgetary decision making such as in NISKANEN [1971], MIGUE and BELANGER [1974] and ROMER and ROSENTHAL [1979]. The executive has power as an agendasetter and may impose a budget that yields a higher level of expenditure than the budget most preferred by the median legislator. The solution of this problem can be found as follows. The median legislator, $L$, will approve every proposal that provides him the same or more utility than the 'status quo'. The set of proposals that satisfies this condition will be called his preference set $P_{L}(S Q)$. In general, for actor $i$ this set is defined as follows:

7. Therefore, not the actual use of power but the attribution of authority to specific actors is important. This implies, for instance, that the number of voter initiatives or the number of veto's of the mayor in strong mayor-council forms of local govemment does not provide a valid indication of their influence in budgetary decision making processes. Even without the use of their power, as will be shown, the outcome of decision making may be adapted towards their preferences.

8. A set of strategies is a subgame perfect (Nash) equilibrium if (1) it is an equilibrium for the entire game, and (2) the actions prescribed by the strategies are an equilibrium for every subgame. A subgame can be defined as the remaining actions after any series of actions by the players.

9. For simplicity, players are assumed not to prefer weakly dominated strategies. 


\section{BERNARD STEUNENBERG}

$$
P_{i}(S Q)=\left\{E \mid U_{i}(E) \geq U_{i}(E(S Q))\right\}
$$

with $E(S Q)$ as the reversion level of expenditure or 'status quo'. Given the preference set of the median legislator the executive will search for the highest level of expenditure.

Define $E^{\prime}(L)$ as the level of spending $E$ for which $U_{L}(E)=U_{L}(E(S Q))$. The ideal point of the median legislator will be denoted as $E^{*}(L)$. Assume that $E^{*}(L)>E(S Q)$. If the executive proposes a budget $E>E^{\prime}(L)$, the proposal will not be accepted by the legislature. The 'status quo', as the best altemative attainable, will be approved. In that case the outcome provides the executive less utility than some of the alternatives in $P L(S Q)$ because $E^{\prime}(L)>E(S Q)$. So, the executive will propose a budget $E=E^{\prime}(L)$, which will be accepted by the legislature and contains the highest feasible level of expenditure.

If the most preferred expenditure level of the median legislator is lower than the reversion level, $E^{*}(L) \leq E(S Q)$, the executive will not be able to reach a higher spending level than the 'status quo'. He must propose a budget $E=E(S Q)$, which will be approved by the legislature. The new budget is equal to, for example, last year's budget, which means that the executive will not perceive a rise of his utility. However, the agenda-setting power of the executive prevents the approval of a lower budget and, thus, a reduction of his utility if $E^{*}(L)<E(S Q)$.

The equilibrium outcome of budgetary decision making under the "traditional' arrangement is $E=\max \left\{E^{\prime}(L), E(S Q)\right\}$. If the executive proposes a budget for which $E>\max \left\{E^{\prime}(L), E(S Q)\right\}$, the proposal will be rejected by the legislature, and the 'status quo' will be the new budget. This result is comparable to a proposition derived by ROMER and ROSENTHAL $[1979,570]$ for fiscal referenda. They examined the case in which the executive formulates a budget proposal that has to be approved by voters. Then, the agenda setter is able to exploit the difference between the ideal point of the median voter and the 'status quo' or reversion level. However, as will be shown in this paper, this result changes if other institutional arrangements are introduced.

Of course, if we change the procedure by allowing the legislature to amend the proposal of the executive, the outcome will be the budget most preferred by the median legislator. The executive proposes $E=E^{*}(L)$, because any other proposal will be amended to this point and, as a strategy. will yield a lower payoff. In this case the legislature dominates the budgetary process, contrary to the preceding case of agenda setting power of the executive. 


\section{REFERENDUM}

\section{Bureaucratic Agenda Setting Power}

The first institutional arrangement that will be examined is an obligatory fiscal referendum. Under this arrangement voters have to approve a higher tax rate if the legislature agrees on a higher level of expenditure as the new budget. This institution provides voters a form of veto power. The procedure that will be used is:

1. An executive proposes a budget (and, thus, a tax rate),

2. the legislature has to approve or reject the proposal without amendments, and

3. voters have to approve any increase of the tax rate (or level of expenditure). Thus, if $E>E(S Q)$, a referendum is held.

In this case the executive is assumed to be an agenda setter. After solving this problem, the next section will focus on the case in which the legislature may amend the budget and is the agenda setter with respect to a referendum.

The executive is faced with the problem that the legislature has to agree on the budget, and if he proposes a higher level of spending than the 'status quo'. the proposal also has to be approved by voters. Let $E^{*}(V)$ denote the spending level most preferred by the median voter. Assume that $E^{*}(L)>E^{*}(V)$, which indicates that the median legislator has a higher demand for public expenditure than the median voter. For the moment, also assume that the reversion level is smaller than the median voter's most preferred budget, thus: $E(S Q)<E^{*}(V)$. This case may occur if the 'status quo' level of spending is relatively small. An extreme example can be found in some school districts in the U.S. where no spending is allowed when a new budget is not approved. Then, the 'status quo' equals zero. The preferences of the median voter and the median legislator and a 'status quo' are depicted in Figure 1.

If the executive proposes $E=E^{\prime}(L)$, which is the solution of the 'traditional' arrangement, the legislator will approve the requested budget. Because $E^{*}(L)>E(S Q)$, the proposed level of spending, $E^{\prime}(L)$, is larger than the "status quo', $E(S Q)$. So, as indicated, the budget also has to be approved by voters in a referendum. However, the median voter prefers the 'status quo' to $E^{\prime}(L)$, because it is closer to his ideal point and, thus, yields more utility. The median voter will, therefore, reject the proposed budget in favor of the existing level of spending. This outcome is not advantageous for the executive and the median legislator who both (weakly) prefer any proposal from the interval $\left[E(S Q), E^{\prime}(L)\right]$ to this outcome, including a budget equivalent to the ideal point 
Figure I

Preferences for Voters and Levialators

$E^{*}(L)>E^{*}(V)$

low spending

high spending

\begin{tabular}{lllll}
\hline & & & & \\
$E(S Q)$ & $E^{\star}(V)$ & $E^{\prime}(V)$ & $E^{*}(L)$ & $E^{\prime}(L)$
\end{tabular}

of the median voter. This suggests that an incentive exists to propose and approve a budget that does not lead to $E(S Q)^{10}$.

The outcome can be found working backwards. Define $E^{\prime}(V)$ as the budget for which the median voter is indifferent to $E(S Q)$. In the last stage the median voter will accept all proposals in his preference set $P V(S Q)$, which is equivalent to the interval $\left[E(S Q), E^{\prime}(V)\right]$. In the second stage the legislature has to approve the proposal of the executive. The preference set of the median legislator is $P L(S Q)$, which is equal to the interval $\left[E(S Q), E^{\prime}(L)\right]$. Because the legislature will decide a budget that will be approved by voters, only proposals in the intersection of $P_{L}(S Q)$ and $P V(S Q)$ will not be rejected. Maximizing the level of expenditure the best choice the executive can make is to propose a budget $E=E^{\prime}(V)$. This budget will be approved by the legislature and accepted by a majority of voters.

The preferences in Figure $I$ are typical because it is assumed that $E^{*}(V)>E(S Q)$. If the 'status quo' reflects preferences of the executive and the legislature, the median voter most likely prefers a smaller budget than the reversion level, and the outcome will differ from the one just derived. If $E^{*}(V) \leq E(S Q)$, the executive will propose a budget $E=E(S Q)$, because any budget larger than $E(S Q)$ will be rejected by voters. In this case, voters do not have to be consulted, and the legislature approves the 'status quo' as the new budget.

10. Even the median voter has an incentive to change the outcome, if the proposed budget is an element of his preference set. However, the median voter is only able to accept or rejoct proposals that are approved by the legislature. 


\section{REFERENDUM, INITATTVE, AND VETO POWER}

So, the following result is derived:

Proposition 1: Under a obligatory fiscal referendum, and if the executive is an agenda-setter, the unique subgame perfect equilibrium outcome is $E=\max \left\{E^{\prime}(V), E(S Q)\right\}^{11}$.

\section{No Bureaucratic Agenda Setting Power}

So far the executive is assumed to be an agenda setter, and the legislature is not able to amend the executive's proposal. This arrangement will be changed as follows:

1. An executive proposes a budget,

2. the legislature has the authority to amend this proposal and determines the budget, and

3. voters have to approve any increase of the tax rate.

The executive no longer has power as an agenda setter, and the legislature has a more dominant role in the decision making process. The main limitation is imposed by voters, who have to compare a proposal with the 'status quo' if it results into a higher level of spending.

Assume, again, that the median legislator prefers a higher spending level than the median voter, $E^{*}(L)>E^{*}(V)$, and, temporarily, that the 'status quo' has a relatively small value, that is: $E(S Q)<E^{*}(V)$. Because the legislature is able to amend the executive's proposal, the bureaucracy is powerless and does not affect the equilibrium outcome. If $E^{\prime}(V)<E^{*}(L)$, the executive has to propose $E=E^{\prime}(V)$. This level of spending provides the median legislator most utility

11. The special case of a median legislator with relatively low demand for public expenditure is also investigated. Thus, $E^{*}(L)<E^{*}(V)$. If $E(S Q)<E^{*}(L)$, the executive will propose $E=E^{\prime}(L)$. This budget is an element of the preference set of the median voter as well as the median legislature, and it also yields the highest level of expenditure. If $E(S Q) \geq E^{*}(L)$, the executive can only propose a budget $E=E(S Q)$. Any larger budget will be rejected by the legislature. Now, the median legislator will block any atuempt of bureaucracy to increase public expenditure. So, for relatively low demand of the median legislator, the following result is derived:

Proposition: Under an obligatory fiscal referendum, and if the executive is an agenda-setter, the unique subgame perfect equilibrium outcome is $E=\max \left[E^{\prime}(L), E(S Q)\right)$.

Comparing this result with the case of high demand of the median legislator reveals that the equilibrium outcome depends on the relatively low demanders in the game. If voters are low demanders, the obligatory fiscal referendum effectively limits the executive in trying to increase the expenditure level. If legislators are low demanders, the legislative approval of the budget is the main barrier towards higher levels of spending. 
given the preference set of the median voter $P V(S Q)$. It will, therefore, be accepted by the median legislator as well as a majority of voters. If $E^{\prime}(V) \geq E^{*}(L)$, the legislature is able to have voters accept its most preferred point. In that case the executive proposes a budget $E=E^{*}(L)$.

Proposition 2a: Under an obligatory fiscal referendum, and if the executive is not an agenda setter, the unique subgame perfect equilibrium outcome is $E=\min \left\{E^{\prime}(V), E^{*}(L)\right\}$ if the 'status quo' is smaller than the ideal point of the median voter, that is: $E(S Q)<E^{*}(V)$.

If the reversion level is larger than the budget most preferred by the median voter, or $E^{*}(V) \leq E(S Q)$, the equilibrium outcome changes and depends on the location of the 'status quo' vis- $d$-vis the ideal point of the median legisiator. If $E^{*}(L) \geq E(S Q)$, a majority of voters prefers a smaller budget than $E(S Q)$, while the median legislator would like to have a larger budget. If the legislator proposes a budget larger than $E(S Q)$, the median voter will not accept this proposal and the 'status quo' will be the new budget. A rather uncommon case occurs if $E^{*}(L)<(S Q)$. Then, the median legislator and the median voter prefer a budget smaller than $E(S Q)$. Such a preference configuration may occur of the 'status quo' is, for instance, last year's budget and voters and legislators suddenly changed their preferences demanding a reduction of public expenditure. Now, the median legislator will approve a budget that reduces the tax rate. Voter approval is not obliged in this case, and a referendum will not be held. The equilibrium outcome is $E=E^{*}(L)$.

Proposition $2 b$ : Under an obligatory fiscal referendum, and if the executive is not an agenda setter, the unique subgame perfect equilibrium outcome is $E=\min \left\{E(S Q), E^{*}(L)\right\}$ if the 'status quo' is larger than or equal to the ideal point of the median voter, that is: $E(S Q) \geq E^{*}(V)^{12}$.

Figure 2 summarizes the equilibrium outcomes of Proposition 2 (no bureaucratic agenda setting power). These outcomes are provided for different values of the 'status quo'.

12. The special case of relatively bow demand of the median legislator is also investigated. Assume that $E^{*}(L)<E^{*}(V)$ and $E(S Q)<E^{*}(L)$. Voters will acoept all proposals in $P \cup(S Q)$, so the median legislator is able to propose his most preferred level of spending. If $E(S Q) \geq E^{*}(L)$, the median legislator prefers a budget that contains the same or a smaller level of expenditure than the 'status quo'. Recall that a fiscal referendum is only obligatory if the legislature approves a budget that implies a higher tax rate. So, the executive will propose $E=E^{*}(L)$. Because the tax rate remains constant or is even reduced, a referendum will not be held, and $E^{*}(L)$ is the new budget.

Proposition: Under an obligatory fiscal referendum, and if the executive is not an agenda setter, the unique subgame perfec equilibrium outcome is $E=E^{*}(L)$. 
Figure 2

\section{Bquilibrium Outcome for Referendum}

No Bureancratic Afendi Control

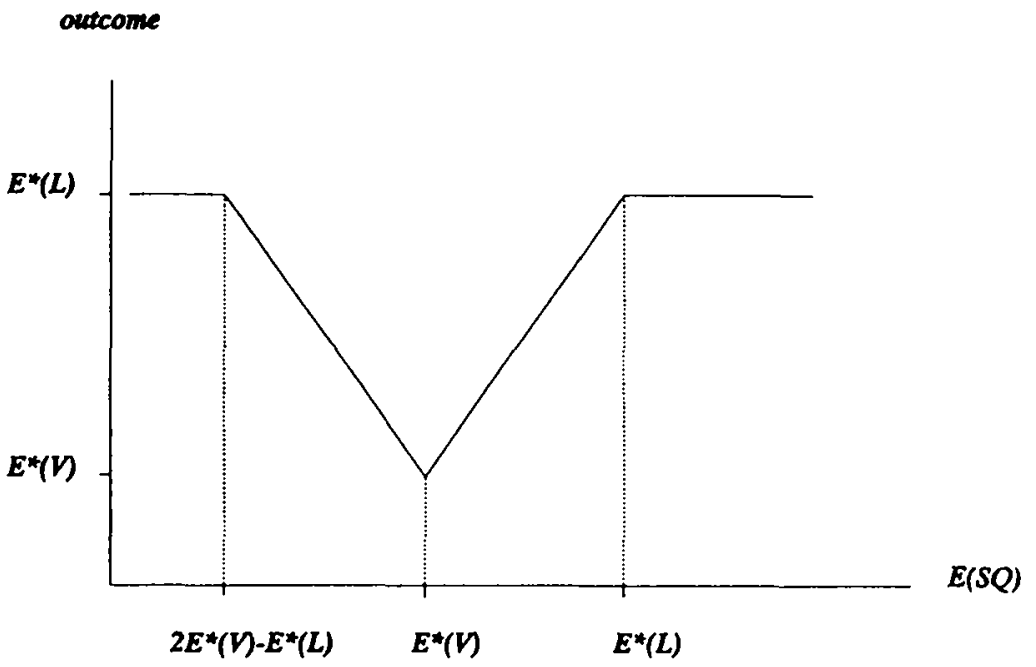

Several observations can be made. First, the effect of a referendum is sometimes small or even nonexistent. If $E(S Q) \geq E^{*}(L)$, a referendum does not affect the outcome of budgetary decision making. This is also true for small values of the 'status quo', that is: $E(S Q) \leq E(L)-2 E^{*}(V)$, and if the legislature does not face a bureaucratic agenda setter. If the executive does have agenda setting power, the equilibrium outcome is shifted away from $E^{\prime}(L)$ to $E^{\prime}(V)$ in comparison with the 'traditional' arrangement (see Section II.). This difference reveals a constraining effect of voter preferences on the equilibrium outcome. Second, voter preferences are more important for intermediate values of the 'status quo', that is: $E(L)-2 E^{*}(V)<E(S Q)<E^{*}(L)$. Then, the median voter, who prefers a smaller expenditure level, effectively constrains the budget choice. As $E(S Q)$ moves away from a small value towards the ideal point of the median voter, the equilibrium budget becomes smaller. A minimum is reached if $E(S Q)=E^{*}(V)$, and the median voter's most preferred budget is the outcome of budgetary decision making. Third, the absence of agenda setting power clearly reduces the influence of the executive. Depending on the location of the 
'status quo', he is not able to increase public spending to a level higher than the ideal point of the median legislator.

\section{VOTER INITIATIVE}

The second institutional arrangement that will be analyzed is voter initiative. Under initiative, voters have the authority to propose a tax rate, or, in terms of our model, a level of expenditure. In general, two different forms of initiative can be distinguished. The first form is direct initiative. In that case the proposed policy is put directly on a ballot to be approved by voters. Then, beside authority to propose a policy, voters have veto power with respect to their proposals. The second form is called indirect initiative. In contrast to the first form, the legislature has authority to amend a policy proposal before it is voted on in a referendum. This authority provides the legislature veto power in the sense that the proposal can be changed into a more preferred budget.

\section{Direct Initiative}

For direct initiative, the following procedure will be used:

1. An executive proposes a budget.

2. the legislature has to approve or to reject the proposal without amendments,

3. voters may propose another tax rate or spending level (initiative), and

4. voters have to approve their proposal in a referendum.

Using this procedure, voter preferences determine the outcome. If the executive proposes a budget $E=E^{\prime}(L)$, which is the outcome under the 'traditional' arrangement, voters will propose another level of spending if $E^{*}(V) \neq E^{*}(L)$. The reason for this is obvious: Every proposal that is not equal to the most preferred point of the median voter causes a majority of voters to propose and approve an expenditure level that is equal to the median preference. So, the executive is confronted with the constraint that the outcome must be equivalent to $E^{*}(V)$. The budget that will be proposed and is approved by the legislature is, thus, $E=E^{*}(V)$. Note that under these 'ideal' conditions agenda setting power of the executive is not relevant for the outcome. Even if the legislature is able to amend budget proposals, the proposed and approved budget remains $E^{*}(V)$. Of course, the outcome depends on costs voters face in organizing a petition and to have a proposal put on the ballot. If these costs are quite substantial, the threat of initiative may not be credible. In that case, decision 
making is more accurately described with the 'traditional' model in which only the executive and the legislative body decide the budget.

Proposition 3: Under direct voter initiative, the unique subgame perfect equilibrium outcome is $E=E^{*}(V)$.

\section{Indirect Initiative}

Indirect initiative is the second form of voter initiative. Contrary to direct initiative, the legislature is allowed to amend a proposal before voters decide in a referendum. This procedure can be described as follows:

1. An executive proposes a budget,

2. the legislature has to approve or reject this proposal without amendments,

3. voters may propose another tax rate or spending level (initiative),

4. the legislature may amend the proposal of voters, and

5. voters have to approve a proposal in a referendum.

Assume that $E^{*}(V)<E^{*}(L)$ and, temporarily, $E(S Q)<E^{*}(V)$. Preferring a smaller budget than the median legislator, the ideal point of the median voter is larger than the 'status quo'. So, $E^{\prime}(V)$ will be to the right of $E^{*}(V)$. Now, consider the first case in which $E^{\prime}(V)<E^{*}(L)^{13}$. In the last stage, voters will approve a proposal if it is preferred to the 'status quo'. In other words, a successful proposal has to be in the median voter's preference set $P V(S Q)$, which is equivalent to the interval $\left[E(S Q), E^{\prime}(V)\right]$. In the fourth stage, the legislature will amend any initiative to an element of $P v(S Q)$ that yields the highest payoff for the median legislator. Given the ideal point of the median legislator vis-d-vis this set, the legislature will propose $E^{\prime}(V)$. Voters will decide whether or not to organize a petition in the third stage. If the executive's proposal is not in $\left[E(S Q), E^{\prime}(V)\right]$, they will use their authority to introduce a proposal $^{14}$. Knowing this, the legislature will approve a budget equivalent to $E^{\prime}(V)$, which will be proposed by the executive. If the executive still decides to propose another budget, for instance a budget $E>E^{\prime}(V)$, voters will object and use their proposal authority. This strategy, which leads to the same outcome, yields a lower payoff than proposing $E^{\prime}(V)$.

13. Or, $E(S Q) 2 E^{*}(V)-E^{*}(L)$.

14. Again, zero transaction costs are assumed. If these costs are more substantial, decision making under this arrangement is more accurately described with the 'traditional' arrangement in Section II. 
The outcome changes if the 'status quo' is a smaller budget. In other words, $E^{\prime}(V) \geq E^{*}(L)^{15}$. Then, the median legislator is able to propose his ideal point as the new budget in the fourth stage. Because the median legislator's ideal point is closer to the ideal point of the median voter than the 'status quo', this point will be preferred to $E^{\prime}(V)$ or $E(S Q)$. So, a budget equivalent to $E^{*}(L)$ will be the equilibrium outcome. Any other proposal of the exccutive will lead to voter initiative and an amended proposal of the legislature. Again, agenda setting power of the executive is not relevant for the equilibrium outcome.

Proposition 4a: Under indirect voter initiative, the unique subgame perfect equilibrium outcome is $E=\min \left(E^{\prime}(V), E^{*}(L)\right\}$ if the 'status quo' is smaller than the ideal point of the median voter, that is: $E(S Q)<E^{*}(V)$.

A different outcome will occur if the 'status quo' is equal to or smaller than the ideal point of the median voter, while the median legislator prefers a larger budget. Thus, $E(S Q) \geq E^{*}(V)$ and $E^{*}(L) \geq E(S Q)$. Then, the 'status quo' is the only proposal that will be accepted by the legislature and voters. Any budget proposed by the executive and approved by the legislature that implies a higher level of spending than $E(S Q)$, will trigger voter initiative. The result is that such a proposal will be rejected in a referendum in favor of the 'status quo' level of spending. So, in this case the executive will propose $E=E(S Q)$, which is the equilibrium outcome.

Less common is the following preference configuration: $E^{*}(L)<E(S Q)$. Then, the budget most preferred by the median legislator is within the preference set of the median voter $P V(S Q)$. Any voter proposal will be amended to this point before it is put on the ballot, and $E^{*}(L)$ will be approved in a referendum. Because $E^{*}(V)<E^{*}(L)$ and $E^{*}(L)<E(S Q)$, the ideal point of the median voter is closer to $E^{*}(L)$ than $E(S Q)$, and, therefore, $U V\left(E^{*}(L)\right)$ $U_{V}(E(S Q))$. So, anticipating these actions in the next stages, the executive proposes $E=E^{*}(L)$.

15. Or, $E(S Q) 2 E^{*}(V)-E^{*}(L)$. 
Proposition $4 b$ : Under indirect voter initiative, the unique subgame perfect equilibrium outcome is $E=\min \left(E(S Q), E^{*}(L)\right)$ if the 'status quo' is larger than or equal to the ideal point of the median voter, that is: $E(S Q) \geq E^{*}(V)^{16}$.

The equilibrium outcome of this game is equal to the outcome described by Proposition 2. So, the arrangements of an obligatory fiscal referendum and indirect voter initiative have identical effects on the level of public spending.

\section{VETO POWER}

\section{Bureaucratic Agenda Selting Power}

The last institutional arrangement that will be considered is veto power of an elected official with respect to an increase of the tax rate. This authority is comparable to that of mayors in some U.S. cities, who may veto ordinances of city councils. The procedure in this case is:

1. An executive proposes a budgeh,

2. the legisiature may approve or reject the proposal without amendments,

3. an elected official of the executive branch may veto the proposal of the legislature if it implies a higher tax rate, and

4. a veto can be overruled by a two-thirds majority of the legislature.

16. The special case of a median legislator with relatively low demand for public expenditure is also investigated. Assume that $E^{*}(V)>E^{*}(L)$ and $E(S Q) \leq E^{*}(L)$. So, voters prefer the ideal point of the median legislator to the 'status quo', and the executive has to propose $E=E^{*}(L)$. If $E(S Q)$ $>E^{*}(L)$ and $E^{*}(V) \geq E(S Q)$, the only point the preference sets of the median legislator and the median voter have in common is the 'status quo'. So, the equilibrium strategy of the executive is to propose $E=E(S Q)$.

If $E^{*}(V)<E(S Q)$, and $E^{*}(V)>E^{*}(L), E(V)$ is the only budget that yields the highest feasible payoff for the median legislator and is an element of $P Y(S Q)$. So, $E=E^{*}(V)$. If $E^{*}(V) \leq E^{*}(L), E^{*}(L) \in$ $P$ Y $(S Q)$. Now, $E=E^{*}(L)$.

Proposition: Under indirect voter initiative, the unique subgame perfect equilibrium outcome is:

(i) $E=\max \left\{E^{*}(L), E(S Q)\right\}$ if the median voter prefers a budget equal to or larger than the 'status quo', that is : $E^{*}(V) \geq E(S Q)$.

(ii) $E=\max \left(E(V), E^{*}(L)\right)$ if the median voter prefers a budget smaller than the 'status quo', that is: $E^{*}(V)<E(S Q)$.

Note that when the median legislator prefers a smaller budget than the median voter, the outcome is not equivalent to the one for an obligatory fiscal referendum (see Note 11). Furthermore, while the same type of equilibrium outcome is found as for high legislative demand (see Proposition 4). the outcomes in terms of expenditure levels differ, because $E^{*}(V)>E^{*}(L)$. 
The ideal point of the elected official will be denoted as $E^{*}(M)$. Furthermore, $E^{*}(O)\left(\operatorname{or} E^{*}\left(O^{\prime}\right)\right)$ is the ideal point of a legislator, who has one-third of all ideal points of legislators to his left (or to his right). Consequently, $E^{*}(O) \leq E^{*}(L) \leq$ $E^{*}\left(O^{\prime}\right)$. In case a budget proposal is vetoed, the relevant two-thirds majority depends on the value of the 'status quo' vis-â-vis $E^{*}(O)$ and $E^{*}\left(O^{\prime}\right)$. If $E(S Q)<E^{*}(O), E^{*}(O)$ is the ideal point of the legislator who is decisive in case of two-thirds majority voting. If $E(S Q)>E^{*}\left(O^{\prime}\right), E^{*}\left(O^{\prime}\right)$ has to be used. However, if $E^{*}(O) \leq E(S Q) \leq E^{*}\left(O^{\prime}\right)$, none of the proposals in $E$ is able to beat the 'status quo"17. In this case, the legislature cannot override a veto, and if a proposal is vetoed, the 'status quo' will be preserved.

Veto power of the official affects the outcome if $E(S Q)<E^{*}(L)^{18}$. In this case $E^{*}(O)$ is the relevant ideal point of the decisive legislator for two-thirds majority voting. Two cases will be examined: (1) The case for which a two-thirds majority can be formed against the 'status quo', $E(S Q)<E^{*}(O)$, and (2) the case for which a veto of the elected official cannot be overridden by the legislature, $E(S Q) \geq E^{*}(O)$.

$V e t o$ can be overruled. Assume that $E(S Q)<E^{*}(O)$. The problem the executive faces is to find a point he prefers most and that will be accepted by the median legislator, and which also is an element of the preference set of the elected official or the decisive legislator in a two-thinds majority vote. Thus, the proposal has to be an element of the intersection of $P_{L}(S Q)$ and $P_{M}(S Q) \cup P O(S Q)$. If his proposal is in $P_{M}(S Q)$, the official will not use his veto power. If the proposal is in $P O(S Q)$, it will be 'protected' by the legislature because a possible veto of the official will be overridden.

Now, assumed that the official prefers the same or a larger level of public expenditure than the median legislator, thus: $E^{*}(M) \geq E^{*}(L)$. This preference configuration may occur if the elected official represents special interests, which favor a high level of public spending. If the executive proposes $E=E^{\prime}(L)$, which is in the median legislator's preference set, the official will not use his veto power because this proposal yields more utility than the 'status quo'.

17. See also BLACX's theorem on special majority voting (1987, 89-90).

18. If $E(S Q) \geq E^{*}(L)$, the rare case occurs that a veto does not have to be considered. As indicated, it is only defined for a proposed tax increase. The best proposal the executive can make is a budget equivalent to the 'status quo'. It conisins the highest level of spending of all proposals in the preference set of the median legislator (see Section II). So, independent of the preference of the elected official, the equilibrium strategy of the executive is to propose $E=E(S Q)$. Thus:

Proposition: Under veto power of an elocted official of the executive branch. and if the executive is an agenda setter, the unique subgame perfect equilibrium outcome is $E=E(S Q)$ if the 'status quo' is equal to or larger than the ideal point of the median legislator, that is: $E(S Q) \geq E^{*}(L)$. 
The elected official might not be 'captured' by special interests. If he represents a majority of voters who prefer less spending than the median legislator, his ideal point can be found to the left of $E^{*}(L)$. If $E^{*}(O) \leq E^{*}(M)$ and $E^{*}(L)>E^{*}(M)$, the official prefers a smaller budget than the median legislator, but still favors more public spending than the legislator who is decisive in a two-thirds majority vote. Because $E^{*}(L)>E^{*}(M), E^{\prime}(L)>E^{\prime}(M)$ with $E^{\prime}(M)$ as the elected official's point of indifference to $E(S Q)$. So, if the executive proposes $E^{\prime}(L)$, the official does not prefer a budget $E^{\prime}(L)$ to the 'status quo' anymore. He will veto the proposed budget $E^{\prime}(L)$. The legislature will not override this veto, because a two-thirds majority prefers $E(S Q)$ to $E^{\prime}(L)$. Now, the executive can propose a budget $E=E^{\prime}(M)$. This proposal is veto proof and will be accepted by the median legislator.

The following result is derived:

Proposition 5a: Under veto power of an elected official of the executive branch, and if the executive is an agenda setter, and if a veto can be overruled, that is: $E(S Q)<E^{*}(O)$, the unique subgame perfect equilibrium outcome is $E=\min \left\{E^{\prime}(L), E^{\prime}(M)\right\}$ if the clected official prefers public spending at least as much as the legislator who is decisive in a two-thirds majority vote, that is: $E^{*}(M) \geq E^{*}(O)$.

The preference of the elected official may deviate more substantially from the median legislator. If $E^{*}(M)<E^{*}(O)$, the elected official favors a smaller level of expenditure than two-thirds of all legislators. The executive may exploit this difference by proposing $E=E^{\prime}(O)$. $E^{\prime}(O)$ is defined as the point of indifference to $E(S Q)$ for the legislator with the ideal point $E^{*}(O)$. Because $E^{*}(O) \leq E^{*}(L)$ and $E(S Q)<E^{*}(O)$, the proposal will be in the preference set of the median legislator and legislator $O$. The official will not use his veto power, because a possible veto will be overruled.

Proposition 5b: Under veto power of an elected official of the executive branch, and if the excecutive is an agenda setter, and if a veto can be overruled, that is: $E(S Q)<E^{*}(O)$, the unique subgame perfect equilibrium outcome is $E=E^{\prime}(O)$ if the elected official prefers a lower lcvel of public spending than the legislator who is decisive in a two-thirds majority vote, that is: $E^{*}(M)<E^{*}(O)$.

Figure 3 summarizes the equilibrium outcomes in case of veto power of an elected official and a bureaucratic agenda setter. These outcomes are provided for different ideal points of the elected official.

Veto cannot be overruled. Now, assume that $E(S Q) \geq E^{*}(O)$. So, a veto cannot be overridden by the legislature. In the last stage the elected official has 
Figure 3

Equfibrim Outeone for Mocted Osictal whit Veto Power:

Bureanarate Agenda Setter and Veto can be overroled

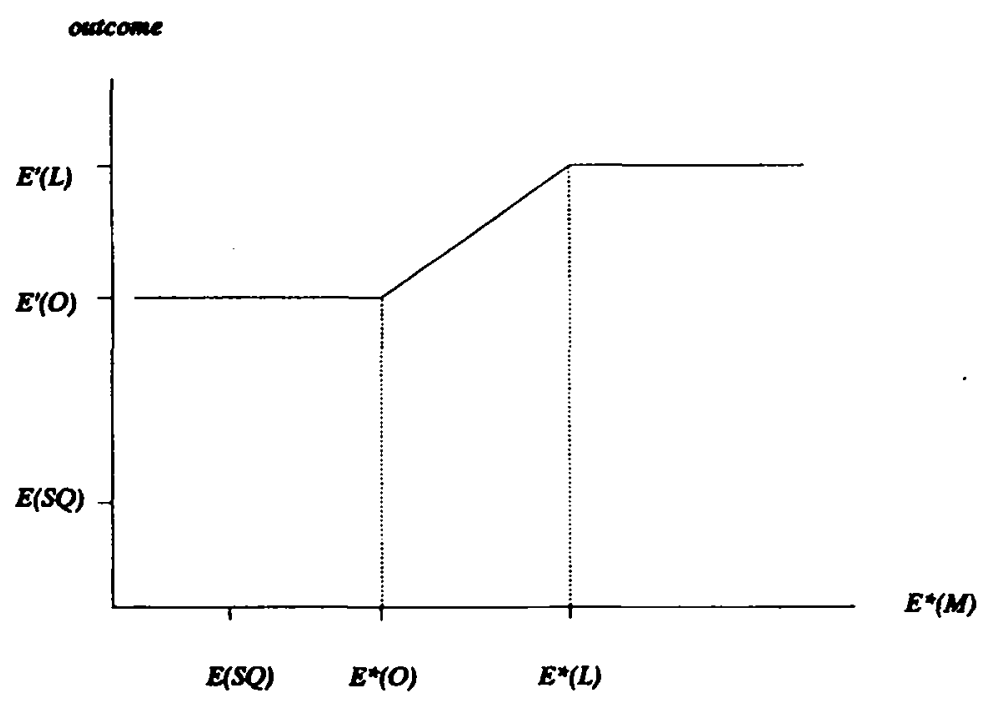

to decide whether or not to veto the propased budget. The executive's problem is to find a budget that is in the preference set of the median legislator as well as the preference set of the elected official, or $P L S Q) \cap P_{M}(S Q)$. Moreover, it is assumed that $E(S Q)<E^{*}(L)$ to avoid overlap with the case for which veto power of the elected official is not defined ${ }^{19}$.

Assume that the ideal point of the official is equal to or larger than the ideal point of the median legislator, $E^{*}(M) \geq E^{*}(L)$. The preference set of the median legislator now is a subset of the official's preference set, so the executive can propose a budget $E=E^{\prime}(L)$. This budget will be approved by the legislature, and the elected official will not use his veto power. If $E^{*}(M)<E^{*}(L)$ and $E^{*}(M)>E(S Q)$, the executive's proposal is $E=E^{\prime}(M)$. If he proposes, for example, $E^{\prime}(L)$, it will be vetoed by the official. Then, the 'status quo' will be the new budget, which is less than $E^{\prime}(M)$.

19. See Note 18. 
Proposition 6a: Under veto power of an elected official of the executive branch, and if the executive is an agenda setter, and if a veto cannot be overruled, that is: $E(S Q) \geq E^{*}(O)$, the unique subgame perfect equilibrium outcome is $E=\min \left\{E^{\prime}(L), E^{\prime}(M)\right\}$ if the official prefers a higher level of public spending than the 'status quo', that is: $E^{*}(M)>E(S Q)$.

This outcome changes if $E^{*}(M) \leq E(S Q)$. Then, the official will veto any proposal that contains an expenditure level that exceeds the 'status quo'. Because a veto cannot be overruled, the executive has to propose a budget $E=E(S Q)$, which is the equilibrium outcome.

Proposition $6 b$ : Under veto power of an elected official of the executive branch, and if the executive is an agenda setter, and if a veto cannot be overruled, that is: $E(S Q) \geq E^{*}(O)$, the unique subgame perfect equilibrium outcome is $E=E(S Q)$ if the official prefers the 'status quo' or a lower level of public spending, that is: $E^{*}(M) \leq E(S Q)$.

The outcome of budgetary decision making in which a veto cannot be overruled, is summarized in Figure 4. Comparing this outcome with a budget game in which a veto can be overruled (see Figure 3), the following observations can be made. First, veto power has a limited effect on the outcome of budgetary decision making. It allows the elected official to restrain the executive when he prefers less spending than the median legislator. If he prefers more, the official is not able to reach a higher level of spending than $E^{\prime}(L)$. This effect can also be found in KIEWIET and MCCUBBINS [1988], who present a simple model for congressional appropriations decisions in which only the president (the elected official) and Congress are included as players. They also found empirical evidence in favor of the asymmetric influence of veto power. Second, in this paper, which pays attention to the fact that a veto can be overridden too, the influence of the elected official appears also to be limited by $E^{*}(O)$ (Figure 3 ) or $E(S Q)$ (Figure 4). If the ideal point of the elected official is smaller than one of these value depending on whether a veto can be overruled, veto power does not affect the equilibrium outcome. So, beside a maximum of $E^{\prime}(L)$, the elected official is also restrained by these minimum values. Third, note that the difference between both cases of veto power is reduced and, finally, will disappear when the 'status quo' moves toward $E^{*}(O)$. 
Figure 4

Equilibrim Outrome for Flocted Ometal with Veto Power.

Bureancratic Arenda Setter and Veto cannot be overruled

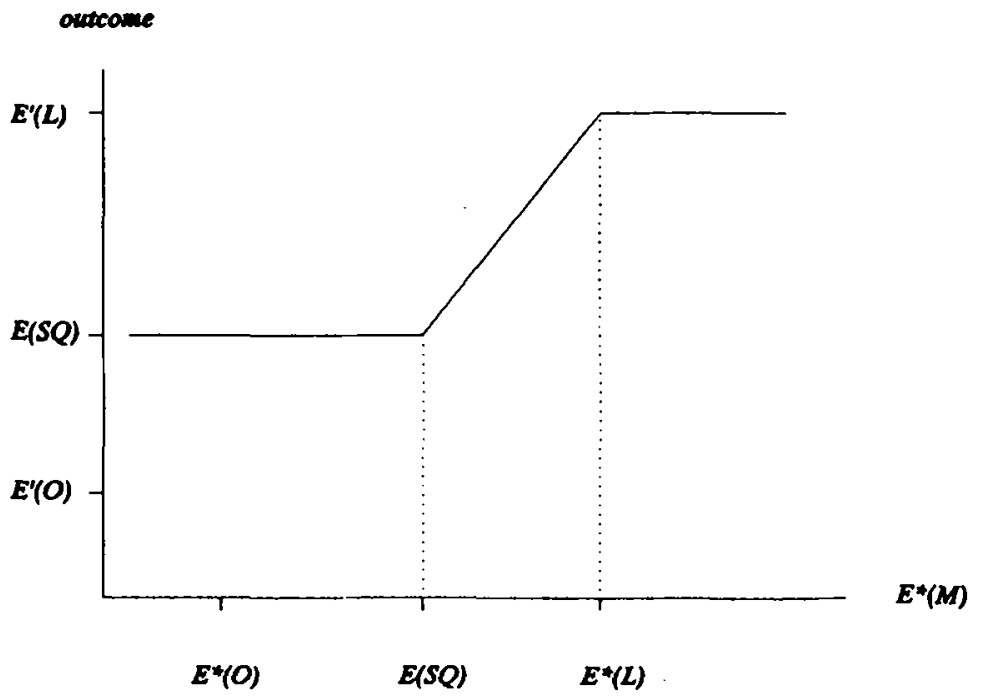

2. No Bureaucratic Agenda Setting Power

Allowing the legislature to amend the proposal of the executive, the procedure described in the preceding section only changes with respect to the second stage. Now, the legislature has the authority to amend the executive's proposal, which reduces the power of the executive, who has to propose a budget that is as close as possible to the ideal point of the median legislator depending on the preference of the elected official or the decisive legislator in a two-thirds majority vote. 
Veto power of the official affects the outcome if $E(S Q)<E^{*}(L)^{20}$. Using $E^{*}(O)$ as the relevant ideal point of the legislator who is decisive for two-thirds majority voting, two cases will be examined: (1) The case in which a two-thirds majority can be formed against the 'status quo' and, therefore, a veto can be overruled, so $E(S Q)<E^{*}(O)$, and (2) the case for which a veto cannot be overnuled, thus: $E(S Q) \geq E^{*}(O)$.

Veto can be overruled. Assume that $E(S Q)<E^{*}(O)$, which is the condition for a successful special majority against the 'status quo'. The executive's problem is to find a point the median legislator prefers most and also is an element of the preference set of the elected official or the legislator who is decisive in a two-thirds majority vote. If a proposal is not in $P_{M}(S Q) \cup P O(S Q)$, it will be vetoed in favor of the 'status quo'.

Assume that $E^{*}(M) \geq E^{*}(O)$. The official prefers the same or a higher level of public expenditure than the median legislator. This implies that $E^{\prime}(M) \geq$ $E^{\prime}(O)$. As long as the ideal point of the median legislator is an element of the preference set of the elected official, thus: $E^{\prime}(M) \geq E^{*}(L)$, the executive has to propose $E=E^{*}(L)$ as the new budget. If $E^{\prime}(M)<E^{*}(L)$, the executive proposes $E=E^{\prime}(M)$. Given that only proposals in $P_{M}(S Q) \cup P o(S Q)$ are feasible, this point provides the median legislator the highest payoff.

Proposition 7a: Under veto power of an elected official of the executive branch, and if the executive is not an agenda setter, and if a veto can be overruled, that is: $E(S Q)<E^{*}(O)$, the unique subgame perfect equilibrium outcome is $E=\min \left\{E^{*}(L), E^{\prime}(M)\right\}$ if the elected official prefers public spending at least as much as the decisive legislator in a two-thirds majority vote, that is: $E^{*}(M) \geq E^{*}(O)$.

These outcomes change if the elected official prefers public spending less than the decisive legislator $O$. So, if $E^{*}(M)<E^{*}(O)$ and $E^{\prime}(O)<E^{*}(L), E^{\prime}(O)$ has to be proposed by the executive. Although this budget is not in the official's preference set because $E^{\prime}(M)<E^{\prime}(O)$, it will be accepted by this player. If he

20. Again, a veto does not have to be considered if $E(S Q) \geq E^{*}(L)$. It is only defined for a proposed increase of the Lax rate. Now, the median legislator is able to have the executive propose his ideal point, which is accepted by majority. So, the equilibrium outcome is $E=E^{*}(L)$ instead of $E(S Q)$, which was the outcome in case the executive can act as an agenda setter (see Seclion II). Thus:

Proposition: Under veto power of an elected official of the executive branch, and if the executive is not an agenda setter, and if the status quo is equal to or larger than the ideal point of the median legislator, that is: $E(S Q) \geq E^{*}(L)$, the unique subgame perfect equilibrium outcome is $E=E^{*}(L)$. 
does veto the bill, his veto will be overruled by a two-thirds majority. If $E^{\prime}(O) \geq$ $E^{*}(L)$, the executive again proposes $E=E^{*}(L)$.

Proposition $7 b$ : Under veto power of an elected official of the executive branch, and if the executive is not an agenda setter, and if a veto can be overnuled, that is: $E(S Q)<E^{*}(O)$, the unique subgame perfect equilibrium outcome is $E=\min \left\{E^{*}(L), E^{\prime}(O)\right\}$ if the elected official prefers a lower level of public spending than the decisive legislator in a two-thirds majority vote, that is: $E^{*}(M)<E^{*}(O)$.

Without bureaucratic agenda setting power, the median legislator is able to induce his ideal point $E^{*}(L)$ as the outcome of decision making instead of the larger budgets $E^{\prime}(L)$ or $E^{\prime}(O)^{21}$, which result if the executive is an agenda setter. A special case occurs if $E^{\prime}(O) \geq E^{*}(L)^{22}$. Then, $E^{*}(L)$ will be the only equilibrium outcome regardless of the preference of the elected official. This effect is due to the fact that in this case the median legislator's ideal point is always in $P O(S Q)$ and, thus, can be proposed without being vetoed.

Veto cannot be overruled. Now, assume that $E(S Q) \geq E^{*}(O)$ implying that a veto cannot be overruled by a two-thirds majority in the legislature. Furthermore, assume that $E(S Q)<E^{*}(L)^{23}$. Because a veto cannot be overridden, the executive has to propose a budget that is an element of only the preference set of the elected official, $P_{M}(S Q)$, instead of $P_{M}(S Q) \cup P O(S Q)$.

Assume that $E^{*}(M)>E(S Q)$, so $E^{*}(M)>E^{*}(O)$. If $E^{\prime}(M) \geq E^{*}(L)$, the median legislator will amend any proposal towards his own ideal point. The proposal $E^{*}(L)$ will not be vetoed because it is in preference set of the elected official and, therefore, yields more utility than the 'status quo'. So, the equilibrium outcome is a budget $E=E^{*}(L)$. If $E^{\prime}(M)<E^{*}(L)$, the ideal point of the median legislator is not in $P_{M}(S Q)$. The proposal that is as close as possible to the median legislator's most preferred point is $E^{\prime}(M)$. Any other proposal closer to $E^{*}(L)$ is valued less by the official and will, therefore, be vetoed. In this case the equilibrium outcome is $E=E^{\prime}(M)$.

Proposition 8a: Under veto power of an elected official of the executive branch, and if the executive is not an agenda setter, and if a veto cannot be overruled, that is: $E(S Q) \geq E^{*}(O)$, the unique subgame perfect equilibrium outcome is

21. If $E^{*}(M)>E^{*}(O)$ and $E^{*}(M)>\frac{1}{2}\left(E^{*}(L)+E(S Q)\right)$, the outcome is $E^{\prime}(L)$, which is larger than $E^{*}(L) . E^{\prime}(O)$ is larger than $E^{*}(L)$ if $E^{*}(M)<E^{*}(O)$ and $E^{*}(O)>\frac{1}{2}\left(E^{*}(L)+E(S Q)\right)$.

22. Or: $E^{*}(O)>\frac{1}{2}\left(E^{*}(L)+E(S Q)\right)$.

23. See Nole 20. 
$E=\min \left\{E^{*}(L), E^{\prime}(M)\right\}$ if the elected official prefers a higher level of public spending than the 'status quo', that is: $E^{*}(M)>E(S Q)$.

If $E^{*}(M) \leq E(S Q)$, the 'status quo' is found between $E^{*}(M)$ and $E^{*}(L)$. Then, the official will veto any proposal that contains an expenditure level larger than the 'status quo'. Because his veto cannot be overruled by the legislature, the executive has to propose a budget $E=E(S Q)$.

Proposition $8 b$ : Under veto power of an elected official of the executive branch, and if the executive is not an agenda setter, and if a veto cannot be overnuled, that is: $E(S Q) \geq E^{*}(O)$, the unique subgame perfect equilibrium outcome is $E=E(S Q)$ if the elected official prefers the 'status quo' or a lower level of public spending, that is: $E^{*}(M) \leq E(S Q)$.

Again, veto power appears to have a limited effect on the outcome of budgetary decision making. The official cannot impose a higher budget than $E^{*}(L)$ if he prefers more public spending than the median legislator. If he prefers less, the outcome is limited by the values $E^{\prime}(O)$ (see Figure 5) or $E(S Q)$ (see

Figure 5

Equilibrim Outcome for Blocted Oncial with Veto Power

No Bareancratic Agenda Setter and Veto can be overroled

case $E^{\prime}(O)<E^{\star}(L)$

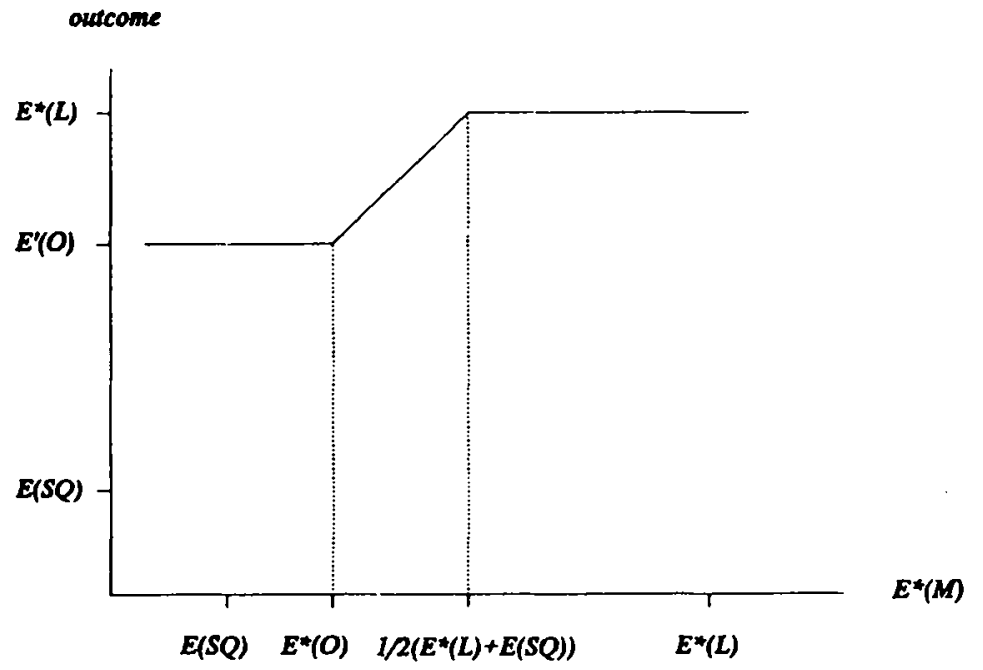


Figure 0). These minimum values are also the main difference between both cases of veto power.

The effect of bureaucratic agenda setting power becomes clear if Figure 5 is compared with Figure 3, and Figure 6 is compared with Figure 4. If the executive has agenda setting power, he may propose a budget up to a maximum of $E^{\prime}(L)$ depending on the preference of the elected official. This maximum is reduced to $E^{*}(L)$ as soon as the legislature has more power and may amend the executive's proposal. So, bureaucratic agenda setting power does matter under the arrangement of veto power, and it may lead to a higher level of public spending.

Figure 6

Equlibrimen Outecene for Docted Oescial with Veto Power No Berreactatic Areada Sedter and Veto cammot be overruled

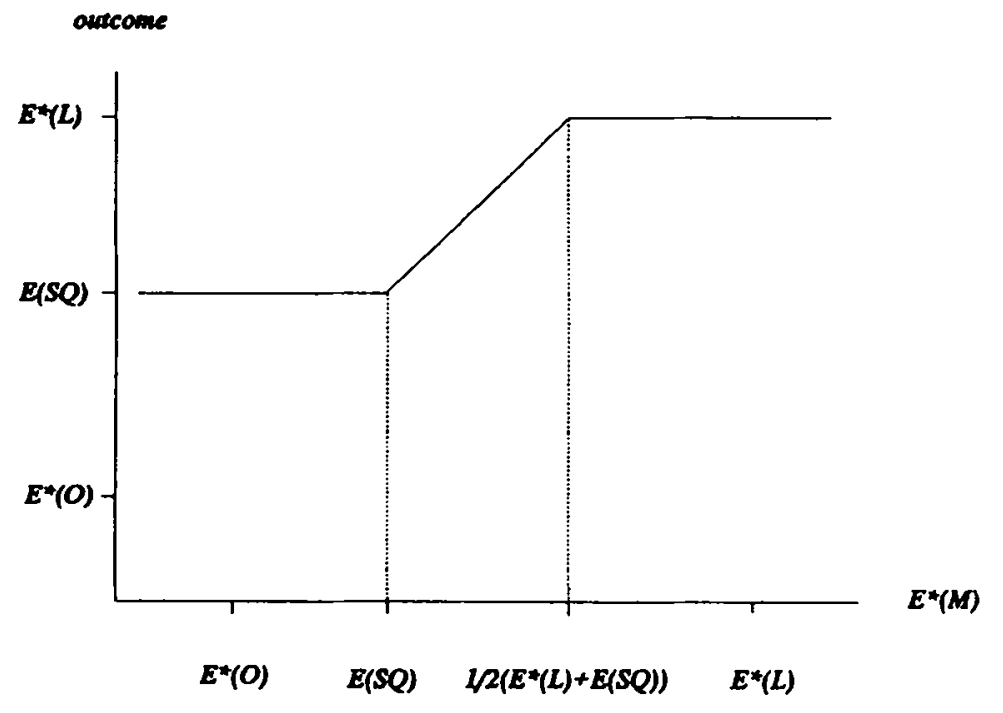




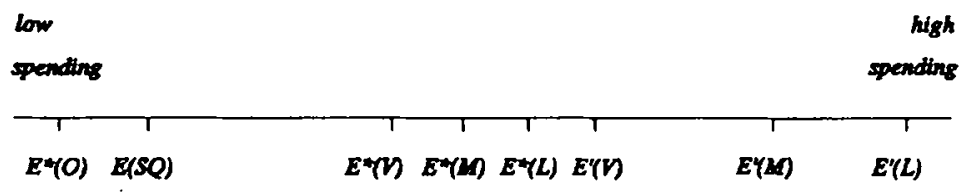

$E^{*}(O)=$ ideal point of legislator who is decisive in two-thinds majority voting

$E(S Q)=$ 'status quo' or reversion level of spending

$E^{*}(V)=$ ideal point of the median voter

$E^{*}(M)=$ ideal point of the elected official

$E^{*}(L)=$ ideal point of the median legislator

$E^{\prime}(V)=$ median voter's point of indifference to $E(S Q)$

$E^{\prime}(M)=$ elected official's point of indifference to $E(S Q)$

$E^{\prime}(L)=$ median legislator's point of indifference to $E(S Q)$

\section{CONCLUSIONS}

The preceding sections offer several equilibrium outcomes for budget games in which different institutional arrangements are used. Besides these arrangements, the outcomes of most games also depend on the preferences of specific actors vis- $d$-vis others and the location of the 'status quo' level of spending. Therefore, any comparison of the effects of different institutional arrangements on expenditure levels has to take into account these factors.

Although comparisons can be made for various preference configurations, some of the main findings will be summarized using a specific preference configuration for voters, legislators, an elected official and the 'status quo'. This ordering, which may resemble preferences in at least some local governments, is the following: $E^{*}(O)<E(S Q)<E^{*}(V)<E^{*}(M)<E^{*}(L)$. Moreover, it is assumed that $E^{*}(L)<E^{\prime}(V)<E^{\prime}(M)<E^{\prime}(L)$ (see Figure 7 ).

According to this ordering, the median voter is assumed to prefer less public spending than the median legislator. The ideal point of the elected official (comparable to a mayor in a strong mayor-council form of government) is located between the median voter and the median legislator. The 'status quo' 
is regarded as a level of spending comparable to, for example, last year's budget and does not have an extremely small value. Furthermore, the 'status quo' is larger than the ideal point of the legislator who is decisive in two-thirds majority voting. So, in case of veto power, a veto of the elected official cannot be overridden by the legislature.

Table I

Comparing Different Institutional Arrangements:

Levels of Public Expenditure

\begin{tabular}{llc}
\hline & \multicolumn{2}{c}{ executive as agenda setter: } \\
& Yes & No \\
- 'traditional' model: \\
$\begin{array}{l}\text { executive-legislature } \\
\text { (Section II.) }\end{array}$ & $E^{\prime}(\Omega)$ & $E^{*}(L)$ \\
$-\begin{array}{l}\text { referendum } \\
\text { (Section III.) }\end{array}$ & $E^{\prime}(V)$ & $E^{*}(L)$ \\
$-\begin{array}{l}\text { direct voter initiative } \\
\text { (Section IV.1.) }\end{array}$ & $E^{*}(V)$ & $E^{*}(V)$ \\
$-\begin{array}{l}\text { indirect voter initiative } \\
\text { (Section IV.2.) }\end{array}$ & $E^{*}(L)$ & $E^{*}(L)$ \\
$-\begin{array}{l}\text { veto power* } \\
\text { (Section V.) }\end{array}$ & $E^{\prime}(M)$ & $E^{*}(L)$
\end{tabular}

- in this example $E(S Q)>E^{*}(O)$, so a veto cannot be overridden by the legislature.

The outcomes of budgetary decision making based on these preferences are summarized in Table 1 . In addition to the different institutional arrangements analyzed in Sections III. to V., the table also contains the outcome for the 'traditional' model, which is described in Section II. According to this model only the executive and the legislature decide the budget.

Comparing the influence of these arrangements on the level of public spending, the 'traditional' model with an executive as agenda setter leads to the highest spending level, $E^{\prime}(L)$. Agenda setting power of bureaucracy also results into relatively high levels of public spending if an elected official has veto 
power or if a fiscal referendum has to be used. These outcomes, $E^{\prime}(M)$ and $E^{\prime}(V)$ respectively, are larger than $E^{*}(L)$, which is the budget in case the legislature can amend proposals of bureaucracy.

If the executive is not an agenda setter, the outcome for the 'traditional' model is the same as the outcome under a fiscal referendum, indirect voter initiative and veto power. However, these arrangements do not always yield equivalent results, and, as indicated, the outcomes in Table $I$ depend on the prefcrence configuration that is used. An exception are referendum and indirect voter initiative. If the median legislator prefers a higher level of public spending than the median voter, these arrangements have identical outcomes. This result is due to the fact that in both cases the median legislator is the agenda setter with respect to the decision of voters in a referendum.

The smallest budget is found for direct voter initiative, the arrangement in which voters actually determine the level of expenditure. Because the median voter is assumed to have the lowest demand for public spending vis-d-vis the other players, this level of spending is not a surprising result. More important is that under the arrangement of initiative voters are able to adapt the outcome of budgetary decision making toward their most preferred point.

In general, the analyzed institutional arrangements allow different political actors to affect the outcome to their benefit. The influence of voters is the largest under direct voter initiative. If a fiscal referendum is required to increase tax rates or if indirect voter initiative is allowed, their influence is reduced in favor of legislators or bureaucracy. An elected official may sometimes adapt the budget level towards his ideal point if he has veto power. Finally, the executive branch, or bureaucracy, has the largest influence on the level of spending if they may determine the agenda in the 'traditional' model.

In this paper the comparison of some institutions of representative government reveals that these arrangements may affect the level of public expenditure. Comparing governments using direct democracy procedures (for example, town meetings) with those using a form of representative government is not simply equal to a case of having a lower or a larger level of expenditure. If, for instance, direct voter iniliative is allowed, the level of public expenditures under a representative arrangement can be equivalent to the level of spending in the case of direct democracy. Political institutions of representative government should not be neglected in comparative analyses. These institutions also matter and affect the level of public expenditure in different ways. 


\title{
BERNARD STEUNENBERG
}

\author{
REPERENCOS
}

Brack, D.: The Theory of Comminees and Elections, Boston: Kluwer Academic Publishers, 1987 [1958].

Cricone, D.L; WAizgr, N. and Deuler, S.C.: 'Representative vs. Direct Democracy and Govemment Spending in a Median Voter Model', Public Finance, Vol. 44 (1989), pp. 225-236.

FARNHAM, P.G.: 'Form of Govemment and the Medien Voter', Social Science Quarterly, Vol. 68 (1987). pp. 569-582.

Parnhay, P.G.: 'The Impact of Citizen Influence on Local Govemment Expenditure', Public Choice, Vol 64 (1990), pp. 201-212.

FREY, B.S.: 'Institutions Matter. The Comparative Analysis of Institutions', European Economic Review, Vol. 34 (1990), Pp. 443-449.

KIEWIET, D.R. and MCCuBans, M.D.: 'Presidential Influence on Congressional Appropriations Docisions', American Journal of Political Science, VoL 32 (1988), Pp. 713-736.

Migut, J.L and BeLnager, G.: 'Toward a General Theory of Managerial Discretion', Public Choice, Vol. 17 (1974), Pp. $27-43$

Morgan, D.R. and Peussero, J.P.: 'Urban Policy: Does Political Strocture Matter?', American Political Science Review, Vol. 74 (1980), pp. 999-1006.

NiskaNeN, W.A.:Bureaucracy and Representative Government, Chicago: Aldine-Atherton, 1971.

POMOMRERNE, W.W.: 'Institutional Approeches to Public Expenditure: Empirical Evidence from Swiss Municipalities', Journal of Public Economics, Vol. 9 (1978), pp. 255-280

Pomarerane, W.W.: 'The Empirical Relevance of Comparative Institutional Analysis', European Economic Review, Vol. 34 (1990). pp. 458-469.

POMmererone, W.W. and SCrenzmer, F.: 'Unbalanced Growth Between Public and Private Sectors: An Empirical Examination', in: Haveman, R.H. (ed.), Public Finance and Public Employment. Proctedings of the 36 th Congress of the International Institute of Public Finance in Jerusalem. 1980. Detroit: Wayne University Press, 1982, pp. 309-326.

Romer, T. and Rosentrul, H.: 'Bureaucrats versus Voters; On the Political Economy of Resource Allocation by Direa Democracy", Quarterly Journal of Economics, Vol. 93 (1979), pp. $561-587$.

SANCERRE, R.E.: 'Representative versus Direct Democracy: A Tiebout Test of Relative Performance'. Public Choice, Vol. 48 (1986). pp. 53-63.

SHEPsie, K.A. and WeDngast, B.R.: 'Structure-induced Equilibrium and Legislative Choice', Public Choice, Vol 37 (1981), pp. 503-519.

ARSTRACT

The paper examines the influence of different institutional amangements of representative govemment. More specifically, the ef fects of (1) obligatory fiscal referendum, (2) voter initiative, and (3) veto power of an elected official of the executive branch (for instance, the mayor) on the level of expenditure are analyzed. Moreover, the influence of agenda setting power of bureaucracy on outcomes is compared with a case in which the legidature is able to introduce amendments.

\section{ZUSAMMENFASSUNG}

In diesem Artikel wird der Einfluss von verachiedenen institutionellen Regelungen in den Vereinigten Staten von Amerika auf eine reprisentative Regierung untersucht. Im einzelnen werden die Effekte von (1) obligatorischen fiskalen Referenda, (2) durch Wähler initiiente Volksbefragungen 


\section{REFERENDUM, INITIATIVE, AND VETO POWER}

und (3) einer Vetomacht eines gewähiten Vertreters einer ausführenden Instiution (wie aum Beispiel der eines Bürgermeisters) auf dem Gebiet öffentlicher Ausgaben untersucht. Darüberhinaus wird der Einfluss von Bürokraten auf die Ergebnisse mit dem Fall verglichen, in dem die gesetzgebende Gewalt eine dominante Position einnimmt gegenūber der Bürokratie.

\section{Résumê}

L'exposé analysel'influence de différentes dispositions institutionelles du gouvemement répresentatif aux U.S.A. On y étudie plus sptcifiquement les effects (1) du refférendum fiscal obligatoire, (2) de l'initiative electeur, el (3) du droit de vélo d'un représentant élu de l'Ex Gcutif (un maire, par exemple) en matière de dépenses. En cutre, l'influence du pouvoir de mise à l’ordre du jour de la bureaucratie sur les résultats est comparte avec un cas ou le légi slateur est compétent pour introduire des amendements. 